\title{
Myoclonic Epilepsy Associated with Ragged-Red Fibers
}

National Cancer Institute

\section{Source}

National Cancer Institute. Myoclonic Epilepsy Associated with Ragged-Red Fibers. NCI

Thesaurus. Code C84889.

A condition that can be caused by mutation(s) in more than one mitochondrial gene. It is characterized by myoclonic epilepsy and ragged-red fibers present on muscle biopsy. 